\title{
Nata De Coco Training for Villagers of Wangon Banyumas District
}

\author{
Author \\ Restu Frida Utami, Putri Dwi Cahyani \\ Correspondence \\ Management Department, Faculty of Economy and Business, Universitas Muhammadiyah Purwokerto \\ restufridautami06@yahoo.co.id
}

\begin{abstract}
IbM entitled "Training Nata De Coco for Communities in Rural Wangon, Banyumas" is aimed to assist partners in solving the problems concerning the use of the coconut water and a lack of knowledge and skills of the communities in Wangon in the use of appropriate technologies for coconut water processing into food products named as Nata De Coco nutritious and high economic value product. This community engagement is purposed to: 1). encourages partners to utilize coconut water which has a lower sale value, 2). give briefing, training and skills for partners in the utilization of appropriate technology for coconut water processing into food products that are nutritious Nata De Coco and high economic value. IbM activity is done by providing training that includes some activities: 1) exposure of the material, 2) giving an example of making Nata De Coco, 3). practice of making Nata directly by the participants. Partners who attended the event IbM is household villagers of Wangon, Banyumas. Attendees were women who belonged to the productive age, but they are simply a housewife. From the implementation of IbM activity, it can be concluded that the participants' awareness and knowledge about the use of coconut water, and procedure of knowledge of making Nata De Coco are increased.
\end{abstract}

Keywords: training, coconut water, Nata de coco

\section{Introduction}

Wangon village is one of the villages located in district Wangon Banyumas district, Central Java. In the village of Wangon coconut fruit is found there, although the fruit is not a reliable agricultural commodity in the village. So far, the utilization of coconuts by the local community has not been maximized. Part of coconut that has been utilized by the local community is shell, coconut fiber and coconut meat, while coconut water, especially coconut water from old fruits into waste is thrown away, so that coconut water has no selling value. Coconut water from the old fruit contains: Protein (0.14 gr), Fat (1.50 grams), Carbohydrates (4.60 grams), Phosphorus (0.50 grams) and water (91.5 grams) (Ketaren in Palungkun, 1992). Coconut water can still be used to be nata food.

Nata is food like a clear white jelly, textured chewy. Nata comes from the Spanish language which means cream, so Nata de coco is a cream that comes from coconut water. The cream is formed by Acetobacter xylinum microorganisms through a fermentation process (Palungkun, 1992).
Received: 30 November 2017. Accepted: 05 January 2018

Nata de coco actually does not have a nutritional value that is meaningful to humans but has high fiber content and low in calories and does not contain fat. The fibers contained in Nata de coco include cellulose, hemicellulose, lignin and watersoluble fiber. High levels of fiber in Nata de coco can be used for digestion, one of which is to smooth the discharge of feces. Nata de coco is low in calories and contains no good cholesterol consumed for people who are on a diet or obese to lose excess weight.

The opportunities to run the business of Nata de coco is still widely open, several factors that support the prospect of Nata de coco are (Director General of Agro-industry Ministry of Industry, $2010 ; 1)$. Indonesia is a country that has the largest coconut plantation in the world, 2). Demand for coconut products of coconut one of them Nata de coco both in the domestic market and the world is still quite prospective, 3 ). In the domestic market the demand for Nata de coco on important events such as the holiday, Christmas, New Year and other events increased sharply. 
The technology of making Nata from coconut water Nata de coco is quite simply so it can be done on a household scale, but many ordinary people who do not know this appropriate technology. Community empowerment in the economic sector through the utilization of waste coconut water into food products that have nutritional and economic value needs to be encouraged. Base on the above problems, efforts are needed to empower people in the village Wangon to utilize the waste into an economically valuable product.

\section{Objectives and benefits}

Community service activities are directed to achieve the following objectives:

1. Encourage the villagers of Wangon village, Wangon district, Banyumas regency to utilize coconut water that has low selling value.

2. Providing knowledge, and skills for the villagers of Wangon village, Wangon district, Banyumas district in the utilization of appropriate technology to process coconut water into Nata de coco nutritious food products which have high economic value.

The expected benefits from these activities are:

1. Wangon village community, Wangon district, Banyumas district has the insight and knowledge to utilize coconut water so that coconut water does not become waste disposal.

2. The Wangon village community, Wangon district, Banyumas district have insight, knowledge and skills in utilizing appropriate technology to treat coconut water into nourishing and high-value Nata de coco food products.

\section{Method}

\section{Partners}

Partners involved in this devotional activity are housewife of Wangon village residents, Wangon district, Banyumas district. Participants who attended the training activities were women who were in productive age, but they did not work or just became housewives. Participants who attended the first stage of IbM activities (making Nata) amounted to 30 people. Participants in the second stage of IbM activities (harvesting Nata) were some of the first representatives from the participants of the first stage of training. The number or participants consist of 10 people. Many women who became the participants in the first stage of the training were not present in the second stage because the methods of harvesting Nata were described in the first stage of the training. In addition, the harvesting process was relatively easier compared to the Nata making process so without being given an example of how to harvest Nata, all participants already understand the process.

This community engagement activity not only provides insight, knowledge and skills to utilize coconut water into a nutritious and economically valuable product to the target audience but also provides an idea and provision to partners to start small business from home by utilizing the waste of coconut water into a product that economic value and can be sold in the market.

\section{Community engagement stages}

The community engagement activities begin with coordination between the devotion team and the partners. The team identified several problems experienced by the partners. After identifying the problem, the next step is to analyze the partner's needs. The team of dedication to the needs of partners is 1) Insight and knowledge about the utilization of coconut water, 2) Insight, knowledge and skill in utilizing appropriate technology to process coconut water into Nata de coco food product.

Based on the result of requirement situation analysis, the devotion team offers solution in the form of training activity of making Nata de coco. This devotional activity is expected to be the solution of partner problems. The following diagram represents problem-solving template framework: 
Problem identification of the partner

1. The villagers of Wangon did not utilize coconut fruit optimally. The coconut water became waste.

2. The villagers of Wangon did not have sufficient skills in using technology to make coconut water become nutritious and high economic Nata de

Analysing partner's needs

Alternative solution for the training program

1. Partner can utilize coconut water

2. Partner can increase their skills in using certain technology to make coconut water become nutritious and high economic Nata de coco products

1. Partner did not waste the coconut water

2. Partner can use certain technology to make nutritious and high economic Nata de coco products

Figure 1. Problem Solving Framework Flow

\section{Troubleshooting process}

The technology transferred to IbM partners using the following training methods and steps:

a. Material exposure. The training begins with the presentation of material on: parts of the coconut fruit and its usefulness, the general description of Nata products, tools and materials needed for the manufacture of Nata, the things that must be considered in making Nata, how to make Nata, how to harvest Nata. Material presentation using lecture and question and answer method. The material is delivered within a period of approximately 30 minutes.

b. Provide examples. After the material explanation, the next step is the team of devotion providing an example of how to make it to the IbM participants. The process of modeling the making of Nata takes about 15 minutes.

Materials needed;

- Coconut Water $=500 \mathrm{ml}=2$ cups mineral water

- Sugar $=17.5 \mathrm{gr}=1$ tablespoon full

- Urea $=3 \mathrm{gr}=$ half a teaspoon

- Vinegar Eating $=20 \mathrm{ml}=3$ tablespoons

- Starter Acetobacter xylinum $=60 \mathrm{ml}=8-9$ tablespoons
Stages of making Nata as follows:

1) Filtering. Coconut water is filtered until no dirt is carried away.

2) Boiling. Coconut water that has been filtered and then boiled until boiling with a large fire while stirred.

3) Mixing. After boiling then mix urea, sugar and vinegar and stir until sugar dissolves.

4) Preparing the container. Prepare a fermentation container that is a tray covered with a newspaper then the edges are tied with rubber and glued with insulation. Give a little gap to enter the mix and starter.

5) Pouring. The mixture is poured into the tray through the gap that has been created with the help of the funnel. Putting the mixture into the tray should be careful not to wet the newspaper.

6) Cooling. The mixture that has been inserted in the tray is then cooled. Then the tray is placed in the fermentation chamber.

7) Inoculation. The cool mixture was then added with Starter Acetobacter Xylinum. Then the standard is closed tightly.

8) Storage. Store the tray in the fermentation room for 10-14 days until a thick layer of Nata is formed. Storage without opening the tray. The fermentation process is strongly influenced by temperature, quality of coconut water, seed condition, space sterilization and equipment that can determine the finished level.

Stages of harvesting Nata as follows:

1) Washing. Nata that has been formed then washed clean.

2) Cutting. Nata that has been washed as desired.

3) Immersion. Soak Nata for 3 days with water every day to remove acid odor.

4) Boiling. Boil Nata until chewy then drain.

5) Added flavor. Boil back Nata in drinking water while added sugar and syrup.

c. Practice by participants. After giving an example of how Nata-making to the participants, the next step is to give participants the opportunity to practice directly to make Nata. Participants are divided into small groups; 
each group consists of 3 people. All participants did the practice of making Nata.

\section{Results and Discussion}

The training activity begins with the presentation of material on the parts of the coconut fruit and its usefulness, the general description of Nata de coco products, the tools and materials needed for the manufacture of Nata, the things that must be considered in making Nata is how to make Nata, and how to harvest Nata.

The materials on the parts of the coconut fruit and their functions are delivered with the aim of the participants to utilize the coconut fruit maximally.

The material on the general picture of Nata products is presented with a view to providing a preliminary understanding for participants about what is meant by Nata products, nutritional content in Nata and business prospects of Nata de coco. Material about the tools and materials needed for the manufacture of Nata, the things that must be considered in making Nata, how to make Nata, how to harvest the Nata delivered with the intention that participants have insight and knowledge of making Nata de coco. The result of this training is the insight and knowledge of the participants increase about the utilization of coconut especially coconut water to be processed into Nata de coco product.

The next activity is to provide an example of making Nata de coco. This activity is intended to provide a clearer picture to the participants about the tools and materials needed, the stages in making Nata, the stages in the harvesting of Nata. This activity resulted in increasing insight and knowledge of participants in using technology to turn coconut water into Nata products.

The activity of dedication ends with the direct practice of making Nata de coco by the trainees. Practical activity is a continuation activity and development of material given in previous activity that is giving example of making Nata de coco. Direct practice activities are intended to ensure that participants have the skills to make Nata de coco. The result of this activity is the participants have the skills and they can make Nata de coco independently.

\section{Conclusion and recommendation}

Some conclusion from this activity are as follows:

1. Nata training activities can provide knowledge and insight to the participants to be able to utilize coconut water so that coconut water is not just for household needs only (drink freshness and food mix) or become waste that is thrown away.

2. The activity of giving the example of making Nata able to provide insight and knowledge in the utilization of appropriate technology to process coconut water into Nata de coco food product.

3. Practical activities undertaken by participants can improve the skills of participants in making Nata so that people are able to make Nata de coco food products are nutritious and high economic value.

Some suggestions are drawn into the following paragraph:

1. To the housewives

Household of Wangon village should use their insights, knowledge and skills, especially in making Nata de coco, so that the existing coconut water is not just for household necessities (refreshments and food mix) or into waste that is thrown away but can be converted into nutritious food products and high economic value.

2. To the local government

The local government needs to encourage the community to utilize the surrounding waste to be a product of economic value.

3. To stakeholders

Owners of capital and business actors have a role in developing community products.

\section{References}

Directorate General of Agro Industry Ministry of Industry.2010. Road Map Coconut Processing Industry. Jakarta

Nugraheni Mutiara.2012. N ata and Health. Semnas 2012 "Increasing the potential of teachers in facing UKG" 
Noni Indriani, Alwani Hamad, Endar Puspa. 2012. Optimization of Nata De Coco Making Process from Coconut Water Fermentation Using Response Surface Methodology. Seminar APTEKINDO. UI.

Palungkun, R., Ed. 1992. Various Coconut Processed Products. Jakarta, UI-Press. 